\title{
Kosovar Refugee Assessments in Montenegro and Albania
}

\author{
Vincent Brown, William Perea, Graziella Godain, Eric Dachy, Marta Valenciano
}

\begin{abstract}
Following NATObombings on the $24^{\text {th }}$ of March 1999, Serbian armed forces provoked a massive population exodus of ethnic Albanians living in Kosovo, an autonomous province of Federal Republic of Yugoslavia. In June 1999, UNHCR reported that 600,000 Kosovars had found refuge in neighbouring countries. In order toassess the situation of Kosovar refugees, two surveys were carried out in Rozaje, Republic of Montenegro, and in Kukes, Albania, in April 1999. The main goal was to assess human rights violations. This paperdescribes the results of these surveys.
\end{abstract}

\section{Résumé}

Suite aux bombardements de l'OTANdu 24 mars 1999, les forces armées serbes ont déclenchéun exodemassifdes populations de souche albanaise du Kosovo, une provinceautonome dela République Fédéralede Yougoslavie. En juin 1999, le Haut Commissariat de l'ONU pour les Réfugiés rapportait que 600,000 kosovars avaient trouvé refuge dans les nations avoisinantes. Danslebutd'évaluer la situation des réfugiéskosovars, deuxenquêtesontété menées à Rozaje, République du Monténégro, età Kikes, Albanie, enavril 1999. Le

Dr. Vincent Brown is a medical epidemiologist who worked withMSF from 1982-93. He is currently working with Epicentre since 1994.

Dr. William Perea worked with MSF from 198895. He is currently a medical epidemiologist with Epicentre since 1996.

Graziella Godain is the Deputy program Director for MSF-French since 1997.

Dr. Eric Dachy is the Deputy Program Director forMSF-Belgium.

Dr. Marta Valenciano is a medical epidemiologist at InVS (Institut national de Veille Sanitaire), department of infectious diseases, based in Paris. but principal desenquêtes était deprendre la mesure des violations aux droits humains. Cetarticledécrit le résultat deces enquêtes.

\section{Introduction}

Following NATObombings on the $24^{\text {th }}$ of March 1999, Serbian armed forces provoked a massive population exodus of ethnic Albanians living in Kosovo, an autonomous province of Federal Republic of Yugoslavia. In June 1999, UNHCR reported that 600,000 Kosovars had found refuge in neighbouring countries ${ }^{1}$.

In order to assess the situation of Kosovar refugees, two surveys were carried out in Rozaje, Republic of Montenegro, and in Kukes, Albania, in April 1999. The main goal was to assess human rights violations. Specific objectives were :

(i) to obtain demographic data and information on basic needs of refugees and corresponding coverage by humanitarian organisations.

(ii) to describe the history of the exodus.

(iii) to assess the impact of the forced migration on mortality amongst Kosovar Albanians.

\section{Methods \\ Study Sites}

Rozajeand Kukes were the main refugee entry sites to the respectivecountries. At the time of the survey, Rozaje had an estimated population of 25,000 refugees, 6,500 of whom where lodged in collective centres. At Kukes, the estimated total was 86,000 refugees among which 36,000 were in camps and in collective centres, 10,000 were in tractor camps and 40,000 living with host families.

\section{Sample Size}

Due to highly insecure working conditions, there was no choice but to rely upon a small sample size. A minimum sample of 200 families, providing a presumed total of 1600 persons (8 persons ) family) was therefore retained for each survey in Rozaje and in Kukes. The surveys covered the events that occurred from March 24 to April 15, and March 24 to April 25, 1999, in the two respective locations.

\section{Sampling Methods}

In Rozaje, 3 out of 10 collective centres, representing 3,000 refugees, were selected by convenience. In each of the 3 centres, one out of two families was randomly selected by systematic sampling.

In Kukes, the survey was limited to the refugees hosted by Albanian families. A modified cluster sampling technique was utilised. A sample of 100 buildings and houses was randomly selected from a map depicting all existing physical structures in the town. Each selected structure was visited. Whenever an apartment building was found, a random sample of two apartments was selected, and Kosovar families living there were interviewed.

A household was defined as all close relatives living together under the same roof in Kosovo when the aerial bombardment began on March 24, 1999. A standard questionnaire containing information on date of arrival, household composition and hosting conditions was addressed to the head of the Kosovar family. For each household, the details of the exodus, the number of missing members, the number and cause of deaths, and vital needs (blankets, mattresses, and food) were recorded. General food distribution was assessed in Rozajeby asking to the fami-

Refuge, Vol. 18, No. 5 (January 2000) 
lies the amount of bread received in the last 24 hours.

Results in percentage were expressed with $95 \%$ Confidence Interval [ $95 \% \mathrm{CI}]$, calculated with the exact interval estimation method and based on two stage cluster sampling.

Data was entered and analysed using Epi-info 6.04b software. ${ }^{2}$

\section{Results}

A total of 406 families were interviewed on the $15^{\text {th }}$ (Rosaje) and on the $25^{\text {th }}$ (Kukes) of April 1999. Males aged 15 to 54 were under-represented in both places (table 1). The average duration of exodus to reach Rozaje and Kukes were 7.6 and 2.7 days (range: $1-23$ and 1-30 days), respectively. The majority of the refugees $(88 \%-357 / 406)$ came from rural areas, from more than 80 different villages, located in Rugova and Prizren regions. Ninety-three percent $(187 / 201)$ of the families in Rozaje arrived by walking. In Kukes, among 70 families from which information could be obtained, $62(89 \%)$ had come by vehicle, mainly tractors.

Amongst both populations, $79 \%$ (321/406, [95\%CI : 73-84]) of the families reported direct physical threat by armed men or by attacks as the main reason for leaving Kosovo. Others left to avoid attack or due to fear of repression. In Rozaje, 46\% (92/201, [95\%CI:36-56]) of the families reported no longer having any identity cards. Refugee cards were not provided to the families on their arrival in Rozaje or in Kukes.

Thirty-one percent $(126 / 406$, [ $95 \% \mathrm{CI}: 25-38$ ]) of families reported " at least one family member left behind ". For the two samples, this amounted toa total of 310 persons, representing $9 \%$ [95\%CI: 8-11] of the total number of persons $[310 /(3,047+310)]$. Among the 141 "left behind" in Kukes, 42 (30\%, [ $95 \% \mathrm{CI}: 20-42]$ ) had been separated by force or detained, 45 (32\%, [95\%CI : 2244]) were Kosovo Liberation Army fighters, 29 (20\%, [95\%CI : 12-32]) stayed voluntarily, and 25 (18\%, [95\% CI : 1029]) reported other reasons (i.e. lost along the way, away from the family at time of exodus, etc).

A total of 13 deaths occurred during the recall period among the 3,047 persons in both sites. Six in Rozaje, from March 24 to April 15 1999, and 7 in Kukes, between March 24 to April 25, 1999. Among the 13 deaths, 7 (54\%, [95\%CI : 17-87]) were due to violence, caused by bullets, bombs or grenades. Other deaths mainly concerned young children and elders who died from " exhaustion " during the exodus.

Concerning basic needs, $8.5 \%$ (17/ 201, [95\%CI : 4-16]) of the families in Rozaje had no blankets and $43 \%(87 /$ 201,95\%CI : 34-54]) had no mattresses.
Families had received an average of 200 grams of bread per person per day (compared to the 300 grams/person/day which had been planned to be distributed). Twenty percent $(41 / 201$, [ $95 \% \mathrm{CI}$ : 13-30]) of the families had not received any bread. In Kukes, only $22 \%(46 / 205$, [95\%CI : 15-32]) of the families had received a blanket, and no mattresses had been distributed. Twenty percent (41/ 205, [95\%CI :13-29]) of the families had not yet received any food parcel. Only $52 \%(107 / 205$, [95\% CI : 42-62]) had received soap. Sixty-two percent (126/ 205, [95\%CI : 51-71]) of the families selected in Kukes paid an average rent of 250 Deustch Marks per month (about 180 USD). Others were accommodated for free or by relatives in Albania.

\section{Discussion}

The surveys conducted in Rozaje and Kukes targeted two different refugee settings in two different host countries. Despite these differences, the refugees' demographic characteristics and history of deportation were similar in both surveys. Based on such evidence, we think that our results could be representative of the populations who sought refuge in Albania and Montenegro.

The history reported by the families surveyed, mainly from villages, confirm the reports of forced deportation orchestrated by the Serbian military forces during this time period. Physical and

Table 1 : Demographics of Survey Population (refugees) in Rosaje, Montenegro, and in Kukes, A lbania, $15^{\text {th }}-25^{\text {th }}$ of A pril 1999.

\begin{tabular}{|l|l|l|l|}
\hline Category & Rozaje & Kukes & Total \\
\hline$\#$ persons & 1537 & 1510 & 3047 \\
\hline \# households & 201 & 205 & 406 \\
\hline \# persons/household & 7.6 & 7.4 & 7.5 \\
\hline M ale :Fem ale ratio (M:F) & $1.00: 1.01$ & $1.00: 1.24$ & $1.00: 1.11$ \\
\hline M :F ratio : 15-54 yrs & $1.00: 1.14$ & $1.00: 1.67$ & $1.00: 1.35$ \\
\hline$\%$ males: 15-54 yrs & $46.8 \%$ & $37.6 \%$ & $42.5 \%$ \\
\hline
\end{tabular}


psychological threats were the main reason reported by families for leaving Kosovo. This forced migration resulted in an unacceptable number of violent deaths among civilians, as well as the creation of many " missing persons "primarily men of fighting age.

The large number of absent family members (i.e. "those left behind") is concerning. Among these absences, $60 \%$ were young male adults, which meant that many families had heads of households who were women and/or elderly. This finding was consistent with the under-representation of males between 15 to 54 years old in the study population which was found in both surveys.

At the time of the survey, the refugees' basic needs had not been adequately covered by relief aid. Many households were lacking such basic items as food, mattresses, blankets, and soap.

In part, this shortcoming maybedue to the absence of an organised refugee registration system, which would make it difficult to ensure that each family received complete food rations and basic non-food items.

\section{Conclusion}

These two community surveys in Montenegro and Albania confirm systematic violations of human rights of the Kosovar Albanians by the Serbian military and paramilitary groups, which are consistent with other reports obtained by individual interviews ${ }^{3,4,5}$. These studies suggest that assistance to the refugees in Montenegro and in Albania have not met international standards. ${ }^{6}$ This failure is especially egregious due to the massive mobilisation of the international community. The protection of the refugees and coverage of their basic needs, including individual registration, remain a high priority during the early stages of such emergencies.

\section{Notes}

1. Kosovo Crisis Update. UNHCRPress Briefings, www.unhcr.ch/news/media/ kosovo.htm, 1999.
2. Dean, A.G., J. A. Dean, and D. C et al. Epi Info, Version 6: a word processing, database, and statistics program for epidemiology on microcomputers. Atlanta, Georgia, U.S.A., Centers for Disease Control and Prevention, 1994

3. War Crimes in Kosovo, A PopulationBased Assessment of Human Rights Violations Against Kosovar Albanians, Physicians for Human Rights, August 1999, USA, Library of Congress Catalog Card N $N^{\circ}$ 99-075785 (www.phrusa.org).

4. US State Department. Ethnic Cleansing in Kosovo: an Accounting. http:// www.state.gov/www/global/ human_rights/kosovoi / homepage.html \#exe: US State Department., 1999.

5. Organization of Security and Co-operation in Europe: Report on Human Rights Findings of the OSCE Mission in Kosovo. http://www.osce.org/kosovo/reports $/ \mathrm{hr} / \mathrm{part2} /$ index.htm ed: OCSE 1999.

6. The Sphere Project, Humanitarian Charter and Minimum Standards in Disaster Response, First Edition 1998, Geneva, http ://www.ifrc.org/pubs/sphere. $\square$

\title{
Paths to EQUity:
}

\section{Cultural, Linguistic, and Racial Diversity in Canadian Early Childhood Education}

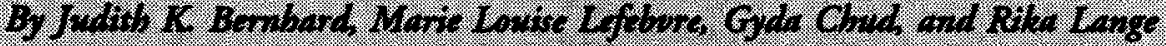

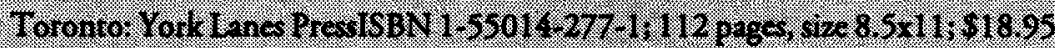

Pathi bo Equigy is besed on an ertensive nationavide study of 77 childcare centres in Montreal, Toronto, and Vancouves on the cultural, Inguistic, and racial diversity in Camadian Early. Childhood Education (ECE). The report pre-ents the resulus this study on how the ECE system 44. responating to the increasing diversity of contemporary Canadian society.

In this ground-breaking study, the authors have dalferved teachers' views on diversity in the

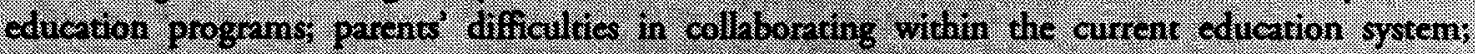

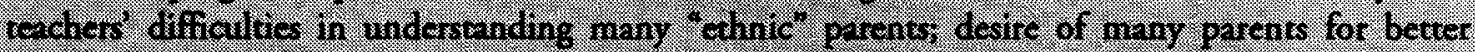
communiction with serf, preferebly in their own hinguges, and for morc information about theit individual dilaten, and chances for effective inputg and the evidence of some continumg problems with maism, irrespective of the good incentions of centre staft.

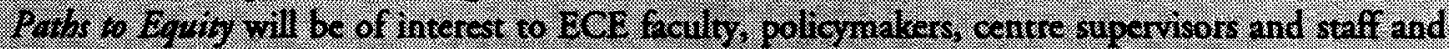
others interested in the inclusion of divessity content in professional educition programs.

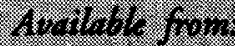

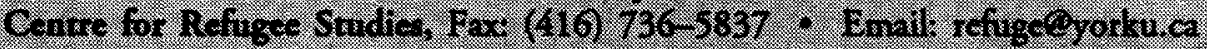

